\title{
Biomaterial Based on Doped Calcium Carbonate-Phosphate for Active Osteogenesis
}

\author{
Lyubov F. Koroleva ${ }^{1}$, L. P. Larionov ${ }^{2 *}$, N. P. Gorbunova ${ }^{3}$ \\ ${ }^{1}$ Institute of Engineering Science of the Russian Academy of Sciences, Ural Branch, Ekaterinburg, Russia; ${ }^{2}$ Ural State Medical \\ Academy, Ekaterinburg, Russia; ${ }^{3}$ Institute of Geology and Geochemistry of the Russian Academy of Sciences, Ural Branch, Ekater- \\ inburg, Russia. \\ Email: *1q@imach.uran.ru
}

Received January $12^{\text {th }}, 2012$; revised February $26^{\text {th }}, 2012$; accepted March $14^{\text {th }}, 2012$

\begin{abstract}
Doped calcium carbonate-phosphate is a biocompatible material that influence actively on the osteogenesis, bone regenerate, strengthening of bone and dental tissues including through the skin. A mechanism of the synthesis reactions of doped nanocrystalline calcium carbonate-phosphate an oscillating type of model for these reactions is proposed. The results indicate that the synthesis involves the formation of hydroxy carbonate complexes from the three calcium carbonate polymorphs (calcite, vaterite, and aragonite) in a solution of ammonium chloride and ammonium carbonate, followed by reaction with orthophosphoric acid. The formation of nanocrystalline calcium carbonate-phosphate doped with $\mathrm{Fe}^{2+}, \mathrm{Mg}^{2+}, \mathrm{Zn}^{2+}, \mathrm{K}^{+}, \mathrm{Si}^{4+}$, and $\mathrm{Mn}^{2+}$, has been studied by X-ray diffraction, IR spectroscopy, differential thermal analysis, and energy dispersive X-ray fluorescence analysis. This ensures the preparation of a bioactive material based on octacalcium hydrogen phosphate, and calcium chloride hydroxide phosphates containing cation vacancies. Particle-size analysis data show that the materials contain nanoparticles down to $10 \mathrm{~nm}$ in size. Heat treatment of the doped calcium carbonate phosphates produces calcium hydroxyapatite containing cation vacancies, which can be used as a bioactive ceramic.
\end{abstract}

Keywords: Doped; Calcium Carbonate-Phosphate; Phosphate Chloride; Synthesis; Oscillating Type; Biocompatible Materials; Osteogenesis; Bone and Dental Tissues

\section{Introduction}

The problems of modern medicine and biotechnology involve not only creation of implants replacing bone tissues and organs, but also synthesis of biologically active materials promoting the fullest restoration of tissues and maintenance of necessary functions of an organism. It is well known that calcium is one of the elements important for a living organism, for its cations control the transporttation of inorganic ions and organic substances through cell membranes in the metabolic process involving the delivery and removal of reaction products from a cell. Interacting with regulatory proteins, calcium participates in nerve impulse transmission to muscles. Calcium is necessary for blood coagulation and participation in the synthesis of hormones, neuromediators and other controlling substances [1]. Calcium is a building material for the bone tissue, its inorganic part. The solid residual of the bone tissue contains $70 \%$ of calcium hydroxide phosphate (calcium hydroxyapatite) $\mathrm{Ca}_{10}\left(\mathrm{PO}_{4}\right)_{6}(\mathrm{OH})_{2}$

"Corresponding author. and $30 \%$ of an organic component, namely, collagen fiber. The bone tissue should be characterized as an organic matrix impregnated by amorphous $\mathrm{Ca}_{3}\left(\mathrm{PO}_{4}\right)_{2}$ and crystals of calcium hydroxide phosphate synthesized in bone tissue osteoblast cells [2].

Ions $\mathrm{Na}^{+}, \mathrm{K}^{+}, \mathrm{Mg}^{2+}, \mathrm{Fe}^{2+}, \mathrm{Cl}^{-}$and $\mathrm{CO}_{3}^{2-}$ are contained in the structure of calcium hydroxide phosphate of the bone tissue besides $\mathrm{Ca}^{2+}$ and $\mathrm{PO}_{4}^{3-}$. The content of anions $\mathrm{CO}_{3}^{2-}$ in calcium hydroxide phosphate of the bone material can make up to $8 \mathrm{wt} . \%$, and they substitute hydroxyl or phosphate groups. Therefore, in view of the carbonate groups introduced into the structure of calcium hydroxide phosphate, its probable formula will be as follows [3-5]: $\mathrm{Ca}_{10}\left(\mathrm{PO}_{4}\right)_{6}\left(\mathrm{CO}_{3}\right)_{\mathrm{x}}(\mathrm{OH})_{2-\mathrm{x}}$.

Actually, the crystal structure, as well as the structure of chemical bonds, of calcium hydroxide phosphate is much more complex because of vacancies in the crystal structure of both anion and cation nature. The vacancies can be filled with bivalent cations of trace elements received by a living organism and with anions $\mathrm{SiO}_{2 x}^{2-}$, $\mathrm{SO}_{4}^{2-}$ and $\mathrm{Cl}^{-}, \mathrm{F}^{-}$. The crystal structure of calcium hydroxyapatite is considered in $[4,5]$ where there is a sim- 
plified form of an elementary cell. However, practically in all scientific works accessible for viewing it is not mentioned that the structure of chemical bonds in calcium hydroxyapatites and apatites of the kind is more complex than their empirical formula and that it is not completely representative. Taking into consideration that phosphoric acids and their salts have basically polymeric structure with the formation of inorganic polymers due to hydrogen bonds and oxygen bridges, one can assume that calcium hydroxide phosphates are also characterized by the formation of inorganic polymers.

It is well known that in an organism there is a complex system of storage and release of calcium, which involves the hormone of the parathyroid gland, calcitonin and vitamin $\mathrm{D}_{3}$. If an organism is unable to assimilate calcium because of age-related and hormonal changes, the lack of calcium begins to be filled with the dissolution of calcium hydroxide phosphate of the bone tissue. As a result, the bone tissue becomes less strong. Besides, deposition of phosphate salts in the cartilaginous connective tissue and on vessel walls is observed. A prominent feature of the growth of bones, teeth and other structures is the accumulation of calcium. On the other hand, the accumulation of calcium in atypical sites leads to the formation of stones, osteoarthritis, cataracts and arterial abnormalities [1]. The entrance of calcium into an organism can proceed in the form of easily assimilated phosphates, which are also necessary for the synthesis of adenosine triphosphoric acid accumulating energy and participating in active transportation of ions through cell membranes. As after 55 the majority mankind suffers from various diseases of joints, lower strength of the bone tissue, osteochondrosis, osteoporosis and frequent fractures, it is necessary to create a material based on inorganic calcium phosphates easily assimilated by a living organism, and not only through the gastrointestinal tract. It is well known that, when calcium phosphate (hydroxyapatite) is introduced into the bone tissue, as a result of slow resorption in an organism and involving in metabolism, osteogenesis improves, but calcium phosphates fail to get into an organism through the skin. The solution to this problem is biomaterial developed on the basis of nanocrystalline doped microelements of calcium carbonate phosphates with a rapid impact on the process of osteogenesis and with the ability to penetrate into the organism through the skin, i.e., through the membranes of living cells [6-8].

Calcium phosphates are studied all over the world. Methods of synthesizing calcium hydroxide phosphates are known. They consist in the following: precipitation from salts of calcium (or hydroxide, or oxide, or carbonate) with addition of $o$-phosphoric acid or mono- or double-substituted phosphate salts with the subsequent hydrolysis in the solution, under hydrothermal conditions, or as a result of pyrolysis [9-23]. Methods for synthesizing calcium hydroxide phosphates are most exhausttively discussed in [4]. It is hardly possible to adduce all the references. The issues concerning methods of production of calcium phosphates, their structure and properties are most fully elucidated in [14].

These are problem of a resorption of calcium hydroxyapatite and osteogenesis in vivo organisms important [24-27]. However, the patent and scientific literature does not offer any preparations based on inorganic calcium phosphates influencing the metabolism of calcium in a living organism through the skin.

The aim of this work is to synthesize calcium carbonate-phosphates doped with cations, which are easily assimilated by a living organism, including through the skin. It presents a study of their crystal phases, chemical composition and particle size analysis, as well as their biological activity in the processes of osteogenesis.

\section{Materials and Methods}

For synthesizing samples of doped calcium carbonatephosphate, calcium carbonate of three crystal structures was used. They are calcite (rhombohedral), vaterite (hexagonal) and aragonite (orthorhombic). Precipitation of calcium carbonate-phosphate was performed by o-phosphoric acid $(2 \mathrm{~mol} / \mathrm{l})$, which was added dropwise into a calcium carbonate suspension in an ammonium chloride solution $(2 \mathrm{~mol} / \mathrm{l})$ at $45^{\circ} \mathrm{C}$ to $55^{\circ} \mathrm{C}$. The size of the $\mathrm{pH}$ environment varied between 5.2 and 6.5 depending on the molar ratio $\mathrm{Ca} / \mathrm{P}$ (1.55 to 1.67$)$. Doping cations were added during calcium carbonate precipitation: $\mathrm{Fe}^{2+}$ and $\mathrm{Mg}^{2+} 0.0004-0.06 ; \mathrm{Zn}^{2+} 0.0015-0.002 ; \mathrm{K}^{+} 0.001-0.01$; $\mathrm{SiO}_{2} 0.0002-0.006$; and $\mathrm{Mn}^{2+} 0.00002-0.001 \mathrm{~mol} \%$. The choice of the calcium-phosphorus-cations-doped molar ratio was caused by the known concentrations of these elements in the bone tissue [1]. The precipitate of synthesized calcium carbonate-phosphates was separated by filtering, washed by water and dried at temperatures not higher than $75^{\circ} \mathrm{C}$.

The samples thus obtained were characterized by $\mathrm{X}$ ray diffraction (XRD) (DRON-2 diffractometer, $\mathrm{CuK \alpha}$ radiation; STADI-P diffractometer, software for diffracttion peak identification using JCPDS-ICDD PDF2 data); IR spectroscopy (Shimadzu JR-475 spectrophotometer, $\mathrm{KBr}$ disk method) and differential thermal analysis (DTG) (MOM thermoanalytical system) at a heating rate of 10 to $11 \mathrm{deg} / \mathrm{min}$ within the range of temperatures from 20 to $1000^{\circ} \mathrm{C}$, with a weight of $500 \mathrm{mg}$. The particle size analysis of the samples was performed by gravitational centrifugal sedimentation with the use of the SA-CP2 analyzer produced by Shimadzu, Japan (dispersion medium viscosity $0.0093 \mathrm{P}$, density $1.0 \mathrm{~g} / \mathrm{cm}^{3}$ ).

The chemical composition $(\mathrm{Ca}, \mathrm{P}, \mathrm{Fe}, \mathrm{Mg}, \mathrm{Zn}, \mathrm{Mn}, \mathrm{K}$, 
and $\mathrm{Si}$ ) was determined by standard techniques of complexometric method [28] and X-ray fluorescent analyses with the use of the EDX-900HS energy dispersion spectrometer (Shimadzu, Japan). The mechanical strength of the bone and dental tissues was studied with the application of the method of stress determination in the bone tissue transverse section [29,30]. The calculation was made by the formula

$$
P=a \frac{F}{S},
$$

where $P$ is mechanical strength (shearing stress), MPa; $a$ is the factor equal to $9.8 ; F$ is the force applied to cut the bone and dental tissues, $\mathrm{kg}-\mathrm{wt}$; $S$ is bone and dental tissue sample shearing area, $\mathrm{mm}^{2}$, determined both by measuring with a microscope and from digital photos with the use of a special program for area calculation. The relative error of the method was $2.5 \%$. Figure 1 is presented apparatus for research transverse mechanical strength of the bone and dental tissues.

\section{Results and Discussion}

\subsection{The Synthesis of Doped Calcium Carbonate-Phosphate}

The mechanism of obtaining this biomaterial is quite difficult, and this process can be considered oscillating reactions of calcium in a living organism. Reaction of the synthesis of doped calcium carbonate phosphates, which were described in [6-8], include several initial compounds as a calcium carbonate of three polymorphic crystal forms (calcite, aragonite, and vaterite), ortho-osphoric acid, ammonium chloride, ammonium hydroxide, and microelements of the living organism $\left(\mathrm{K}^{+}, \mathrm{Mg}^{2+}, \mathrm{Fe}^{2+}\right.$, $\left.\mathrm{Zn}^{2+}, \mathrm{Mn}^{2+}, \mathrm{SiO}_{2}\right)$. The formation of complex of $\mathrm{M}_{g-x} \mathrm{M}_{\mathrm{x}}(\mathrm{OH})_{2}\left[\left(\mathrm{CO}_{3}\right)_{x-2} \cdot \mathrm{H}_{2} \mathrm{O}\right]$ were described in $[7,8]$.

For example, in the medium of ammonium hydroxide,
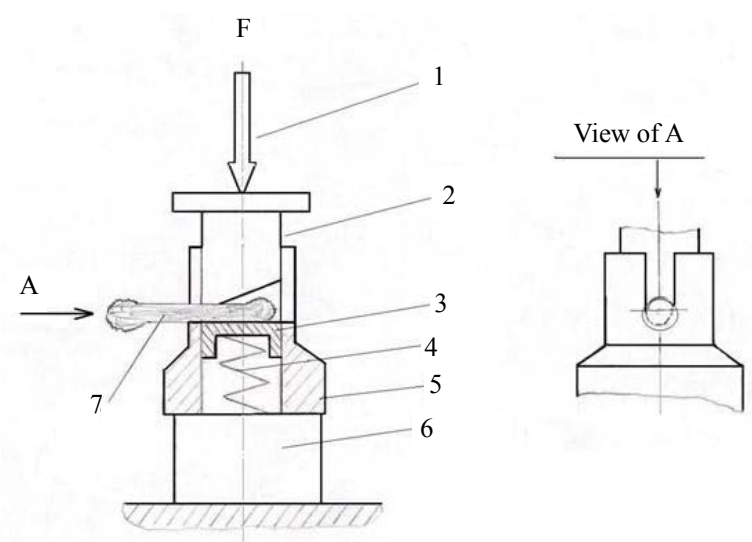

Figure 1. Instrument for research transverse mechanical strength of the bone and dental tissues: 1: screw press; 2: poise; 3: pillar; 4: spring; 5: spigot-matrix; 6: force sensor; 7: sample of bone and dental tissue. three polymorphic forms of $\mathrm{CaCO}_{3}$ can form ammonium met stable hydroxycarbonates complexes on the following scheme:

$$
\mathrm{CaCO}_{3}+\mathrm{NH}_{4} \mathrm{OH} \rightleftarrows \mathrm{NH}_{4} \mathrm{CaCO}_{3} \mathrm{OH}
$$

or, in general form:

$$
\mathrm{A} \rightleftarrows \mathrm{X}
$$

The formation of three types of crystal structures of calcium carbonate (in the medium of ammonium hydroxide and ammonium chloride) is typical for the reaction (1): calcite, vaterite, and aragonite, which was proven by the data of XRD (Figure 2). SEM micrographs of synthetic calcium carbonate: calcite, vaterite, and aragonite shown in Figure 3.

Under the action of ortho-phosphate acid in the presence of magnesium cations and silicon dioxide, carbonate is replaced in the phosphate acid with the formation of $\mathrm{CaHPO}_{4}$ (brushite) or $\mathrm{Ca}_{8} \mathrm{H}_{2}\left(\mathrm{PO}_{4}\right)_{6}$ according to the reaction:

$$
\begin{aligned}
& \mathrm{NH}_{4} \mathrm{CaCO}_{3} \mathrm{OH}+\mathrm{H}_{3} \mathrm{PO}_{4}=\mathrm{NH}_{4} \mathrm{OH}+\mathrm{CaHPO}_{4} \\
& 10 \mathrm{NH}_{4} \mathrm{CaCO}_{3} \mathrm{OH}+6 \mathrm{H}_{3} \mathrm{PO}_{4}=\mathrm{Ca}_{8} \mathrm{H}_{2}\left(\mathrm{PO}_{4}\right)_{6} \\
& +2 \mathrm{CaCO}_{3}+8 \mathrm{CO}_{2}+10 \mathrm{NH}_{4} \mathrm{OH}+8 \mathrm{H}_{2} \mathrm{O}
\end{aligned}
$$

or, in the general form:

$$
\mathrm{B}+\mathrm{X} \rightarrow \mathrm{Y}+\mathrm{C}
$$

In the environment of ammonium chloride with the addition of $o$-phosphoric acid, with the $\mathrm{pH}$ environment from 5.2 to 6.5 , calcium phosphate chloride may form from precipitated calcium carbonate, for example, by the following equation (for convenience of writing equations by integers in a formula, while XRD analysis the number of atoms shows fractional):

$$
\begin{aligned}
& 5 \mathrm{CaCO}_{3}+2 \mathrm{H}_{3} \mathrm{PO}_{4}+2 \mathrm{NH}_{4} \mathrm{Cl}+2 \mathrm{NH}_{4} \mathrm{OH} \\
& =\mathrm{Ca}_{5}\left(\mathrm{PO}_{4}\right)_{2}(\mathrm{OH})_{2} \mathrm{Cl}_{2}+5 \mathrm{CO}_{2}+5 \mathrm{H}_{2} \mathrm{O}+4 \mathrm{NH}_{3} \\
& \mathrm{Ca}_{8} \mathrm{H}_{2}\left(\mathrm{PO}_{4}\right)_{6}+2 \mathrm{CaCO}_{3}+\mathrm{NH}_{4} \mathrm{Cl}+\mathrm{NH}_{3} \\
& \rightleftarrows \mathrm{Ca}_{10}\left(\mathrm{PO}_{4}\right)_{6} \mathrm{OHCl}+2 \mathrm{NH}_{4} \mathrm{HCO}_{3}
\end{aligned}
$$

Description in the general form:

$$
\mathrm{C} \rightleftarrows \mathrm{R}
$$

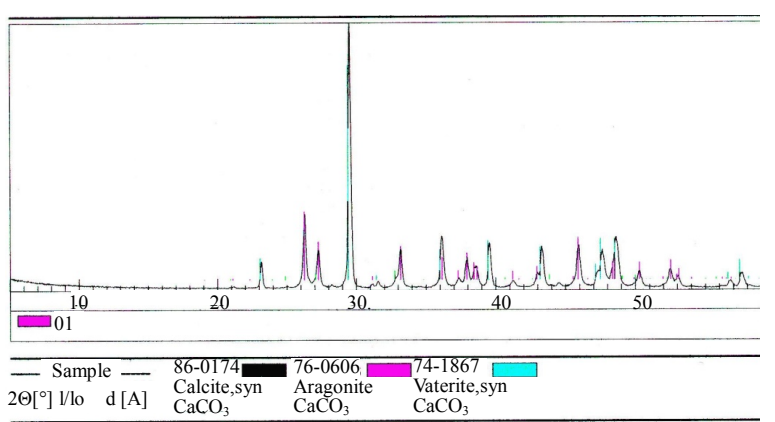

Figure 2. XRD patterns of calcium carbonate: calcite (53 wt \%), vaterite (6 wt \%) and aragonite (41 wt \%). 


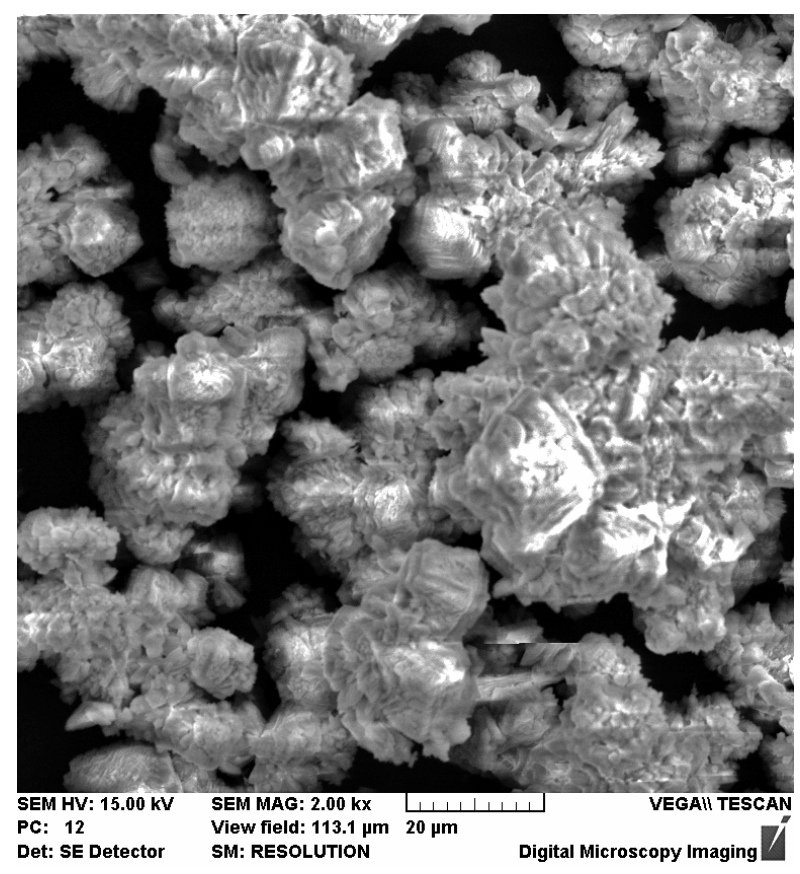

(a)

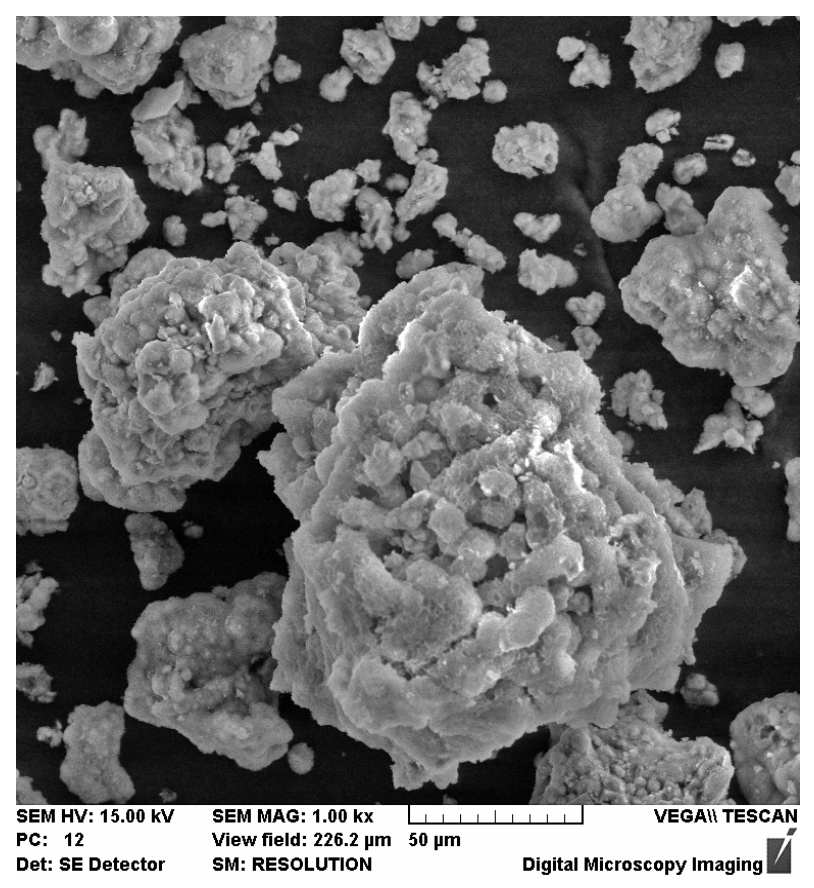

(b)

Figure 3. Scannig electron micrographs of calcium carbonate (a): calcite, vaterite, and aragonite; of doped Fe 0.004; Mg 0.007; Zn 0.002; Mn 0.00002 mol\% calcium carbonatephosphate (b).

According to the law of mass action speed of reaction ( 5 is direct reaction, 6 is reverse reaction) characterize by the equations:

$$
\frac{\mathrm{d} x_{5}}{\mathrm{~d} t}=k_{4}\left[\mathrm{NH}_{4}^{+}\right]\left[\mathrm{Cl}^{-}\right]\left[\mathrm{NH}_{3}\right]
$$

$$
\begin{gathered}
\frac{\mathrm{d} x_{6}}{\mathrm{~d} t}=k_{5}\left[\mathrm{NH}_{4}^{+}\right]^{2}\left[\mathrm{HCO}_{3}^{-}\right]^{2} \\
3 \mathrm{CaHPO}_{4}+2 \mathrm{CaCO}_{3}+2 \mathrm{NH}_{4} \mathrm{Cl}+2 \mathrm{NH}_{3} \\
+3 \mathrm{H}_{2} \mathrm{O}+\mathrm{CO}_{2} \rightleftarrows \mathrm{Ca}_{5}\left(\mathrm{PO}_{4}\right)_{2}(\mathrm{OH})_{2} \mathrm{Cl}_{2} \\
+3 \mathrm{NH}_{4} \mathrm{HCO}_{3}+\mathrm{NH}_{4} \mathrm{H}_{2} \mathrm{PO}_{4}
\end{gathered}
$$

Reaction rate ( 7 is direct reaction, 8 is reverse reaction) characterize by the equations:

$$
\begin{aligned}
& \frac{\mathrm{d} x_{7}}{\mathrm{~d} t}=k_{6}\left[\mathrm{NH}_{4}^{+}\right]^{2}\left[\mathrm{Cl}^{-}\right]^{3}\left[\mathrm{NH}_{3}\right]^{2}\left[\mathrm{CO}_{2}\right] ; \\
& \frac{\mathrm{d} x_{8}}{\mathrm{~d} t}=k_{7}\left[\mathrm{NH}_{4}^{+}\right]^{4}\left[\mathrm{HCO}_{3}^{-}\right]^{3}\left[\mathrm{H}_{2} \mathrm{PO}_{4}^{-}\right] .
\end{aligned}
$$

In addition is transfomation cycle with response:

$$
\mathrm{CaHPO}_{4} \rightleftarrows \mathrm{CaCO}_{3}
$$

Description in the general form:

$$
\mathrm{C} \rightleftarrows \mathrm{A}
$$

Doping of calcium carbonate-phosphate with $\mathrm{Mg}^{2+}$ cations leads to the formation of the following phases in them: octacalcium phosphate hydrogen, brushite, besides, the phases of calcite and aragonite partially remain there. Simultaneous doping with $\mathrm{Fe}^{2+}$ and $\mathrm{Mg}^{2+}$ cations causes the formation of the same phases as in case of introduction of $\mathrm{Fe}^{2+}$ cations alone, however, the calcium hydrogen phosphate $\mathrm{Ca}_{8} \mathrm{H}_{2}\left(\mathrm{PO}_{4}\right)_{6} \cdot 5 \mathrm{H}_{2} \mathrm{O}$ and calcium phosphate chloride hydroxide $\mathrm{Ca}_{9.70} \mathrm{P}_{6.04} \mathrm{O}_{23.86}(\mathrm{OH})_{2.01} \mathrm{Cl}_{2.35}$. The insertion of cations $\mathrm{Fe}^{2+}, \mathrm{Mg}^{2+}$ leads to the basic crystal phase of octacalcium phosphate hydrogen $\mathrm{Ca}_{8} \mathrm{H}_{2}\left(\mathrm{PO}_{4}\right)_{6}$ $5 \mathrm{H}_{2} \mathrm{O}$.

The next stage in the presence of such doping microelements as $\mathrm{Fe}^{2+}, \mathrm{Mg}^{2+}, \mathrm{Zn}^{2+} \mathrm{K}^{+}, \mathrm{Si}^{4+}, \mathrm{Mn}^{2+}$ are generated of calcium phosphate chloride hydroxide (Table 1).

The simplest classic example of the existence of autooscillations in the system of chemical reactions is the trimolecular model ("brusselator") offered by I.R. Prigozhine and R. Lefebre [31]. The main purpose for the study of this model was to determine the qualitative types of behavior, which are compatible with the fundamental laws of chemical and biological kinetics. In this context, the brusselator plays the role of a basic model, like a harmonic oscillator in physics. A classic brusselator model describes the hypothetical scheme of chemical reactions:

$$
\begin{aligned}
& \mathrm{A} \rightarrow \mathrm{X} \\
& \mathrm{B}+\mathrm{X} \rightarrow \mathrm{Y}+\mathrm{C} \\
& 2 \mathrm{X}+\mathrm{Y} \rightarrow 3 \mathrm{X} \\
& \mathrm{X} \rightarrow \mathrm{R} \\
& \mathrm{A}+\mathrm{B} \rightarrow \mathrm{R}+\mathrm{C} .
\end{aligned}
$$

In our case " $\mathrm{A}$ " is raw $\mathrm{CaCO}_{3}$; " $\mathrm{X}$ " is $\mathrm{Ca}$ in hydroxycarbonates complexes $\mathrm{NH}_{4} \mathrm{CaCO}_{3} \mathrm{OH}$; " $\mathrm{B}$ " is $\mathrm{H}_{3} \mathrm{PO}_{4}$; 
" $\mathrm{Y}$ " is $\mathrm{CaHPO}_{4}$ or $\mathrm{Ca}_{8} \mathrm{H}_{2}\left(\mathrm{PO}_{4}\right)_{6}$; " $\mathrm{R}$ " is $\mathrm{Ca}_{9.70} \mathrm{P}_{6.04} \mathrm{O}_{23.86}$ $(\mathrm{OH})_{2.01} \mathrm{Cl}_{2.35}$ or $\mathrm{Ca}_{4.905}\left(\mathrm{PO}_{4}\right)_{3.014} \mathrm{Cl}_{0.595}(\mathrm{OH})_{1.67}$; "C" is generated $\mathrm{CaCO}_{3}$.

The key is the stage of transformation of two $X$ molecules and one $\mathrm{Y}$ molecule into $\mathrm{X}$ (the so-called trimolecular reaction). Such a reaction is possible in processes with the participation of ferments with two catalytic centers. The nonlinearity of this reaction, coupled with processes of diffusion of the substance, well as the formation spatial structures in an initially homogeneous system of morphogenesis. Although the trimolecular stage in chemical kinetics is not as common as in biomolecular processes, expressions for the speed of some chemical reactions in some definite cases can be called cubic-type. Such equations are called "reaction diffusion" equations. The whole system has an oscillating character and can be presented as a brusselator of the simplest implementation of cubic nonlinearity by the following chemical reaction:

$$
2 \mathrm{X}+\mathrm{Y} \rightarrow 3 \mathrm{X}
$$

If the final products $\mathrm{C}$ and $\mathrm{R}$ are immediately removed from the reaction, then the scheme of the reactions (in the case of a point system) can be given by the following system of equations:

$$
\begin{aligned}
& \frac{\mathrm{d} x}{\mathrm{~d} t}=\mathrm{A}+\mathrm{X}^{2} \mathrm{Y}-(\mathrm{B}+1) \mathrm{X} \\
& \frac{\mathrm{d} x}{\mathrm{~d} t}=\mathrm{BX}-\mathrm{X}^{2} \mathrm{Y}
\end{aligned}
$$

Inserting doping cations $\mathrm{Mg}^{2+}$ and $\mathrm{K}^{+}$leads to the synthesis of the basic phase of calcium phosphate hydrogen $\mathrm{Ca}_{8} \mathrm{H}_{2}\left(\mathrm{PO}_{4}\right)_{6}$ as the additional phase of calcium phosphate chloride hydroxide

$\mathrm{Ca}_{9.70} \mathrm{P}_{6.04} \mathrm{O}_{23.86}(\mathrm{OH})_{2.01} \mathrm{Cl}_{2.35}$ (up to 7 wt.\%) and calcium carbonate phosphate and potassium hydrate phosphate hydrogen $\mathrm{Ca}_{8} \mathrm{H}_{2}\left(\mathrm{PO}_{4}\right)_{6} \cdot \mathrm{H}_{2} \mathrm{O}-\mathrm{KHCO}_{3}-\mathrm{H}_{2} \mathrm{O}$ (up to 6 wt.\%, Table 1). The regularities of the concentration changes of hydroxy chlorapatite, chloride, and magnesium in the products of reaction in the synthesis of calcium carbonate phosphate for the reaction with cations $\mathrm{Mg}^{2+}, \mathrm{Fe}^{2+}, \mathrm{Zn}^{2+}$, and $\mathrm{Mn}^{2+}$ are shown in Figure 4.

Table 1. Elemental and phase composition of doped calcium carbonate-phosphate.

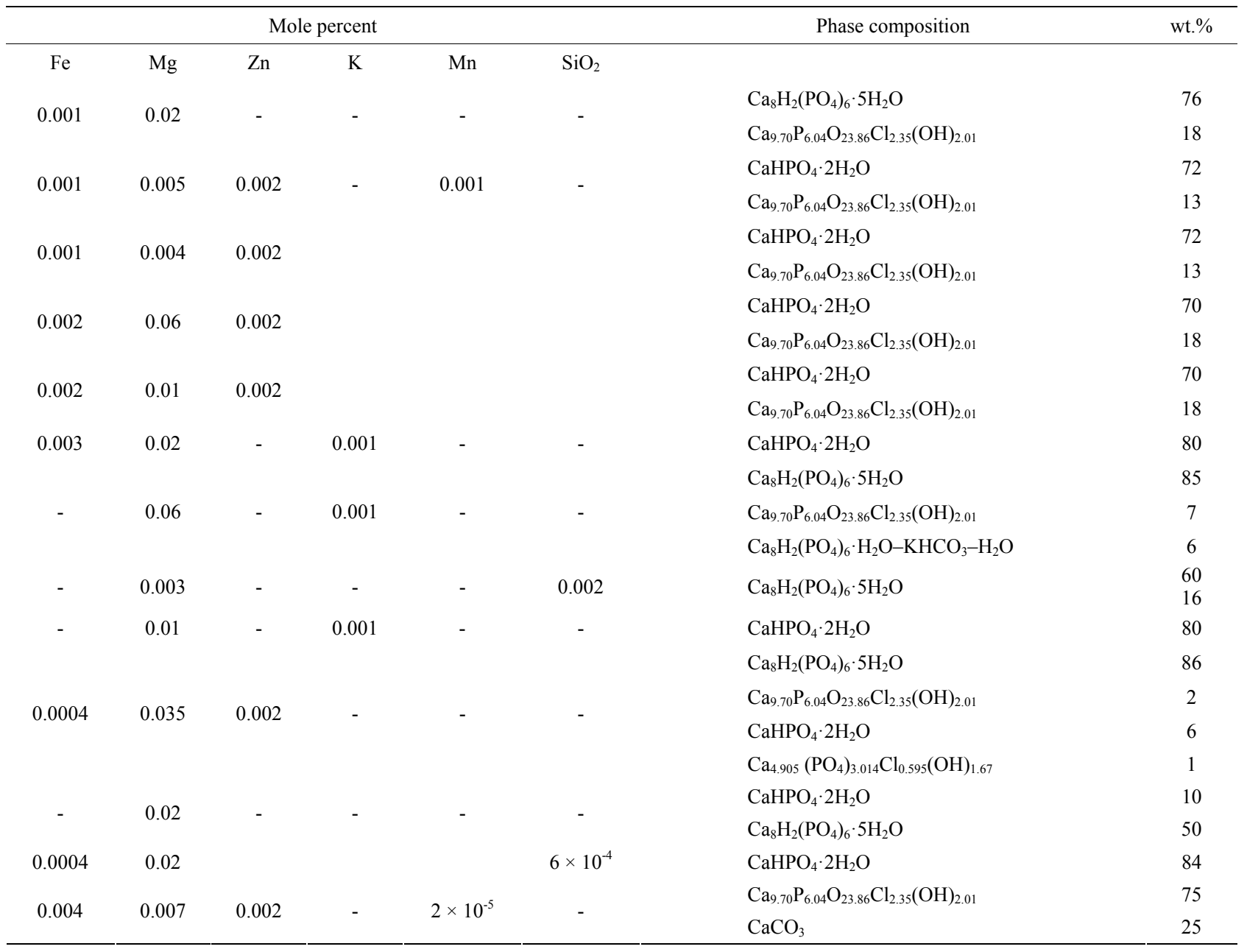




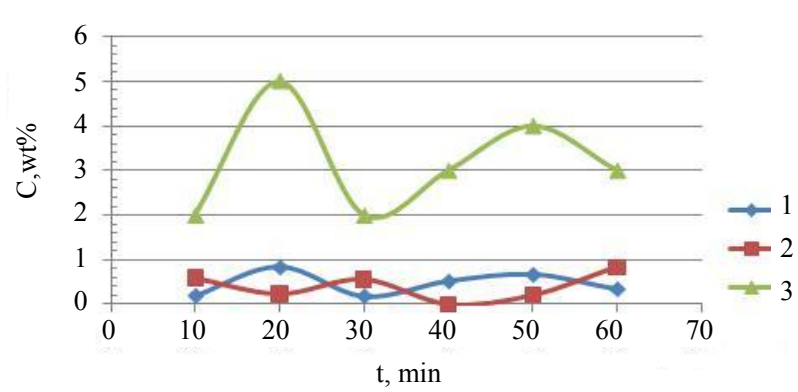

Figure 4. The kinetics of concentration dependencies of the chloride-ions (1), $\mathrm{Mg}^{2+}(2)$ and calcium chloride-hydroxide phosphate (3) precipitation on a time reaction.

The kinetic curves of concentration changes in the synthesis of doped calcium carbonate- phosphate are similar to the kinetics of concentration changes and the phase picture of the fructose-6-phosphate and fructose diphosphate system. Therefore, the oscillating dynamics of the brusselator model and modeling with waves, which are proposed for the fructose-6-phosphate and fructose-diphosphate system in $[31,32]$. For example, see model of intracellular calcium oscillations, as described in [33-37], in Figure 5.

Oscillating character synthesis of the doped calcium carbonate-phosphate remain in the filtering and washing process of the doped calcium carbonate-phosphate precipitation what shown in Figure 6.

The results of X-ray diffraction and chemical analysis confirm this. Typical X-ray diffraction pattern of doped calcium carbonate-phosphate samples are presented in Figure 7. SEM- micrographs of synthetic doped calcium carbonate-phosphate are shown in Figure 3.

The composition is also confirmed by the chemical analysis data and the obtained IR-spectra of calcium carbonate-phosphate samples. Figure 8 presents typical IR-spectra of calcium carbonate-phosphate samples doped with iron, magnesium, zinc, manganese where there are bands of absorption of valence vibration $\delta_{\mathrm{v}}$ of the $\mathrm{PO}_{4}^{3+}$ group 525, 560, $600 \mathrm{~cm}^{-1}$, bands of absorption of symmetric vibrations $v_{1} 865-870$ and $960-980 \mathrm{~cm}^{-1}$ and asymmetric vibrations $v_{3} 1040-1050$ and $1100-1130$ $\mathrm{cm}^{-1}$, and also bands of absorption of the deformation vibration $v_{3}$ of the $\mathrm{CO}_{3}^{2-}$ group $1400 \mathrm{~cm}^{-1}$. The band of absorption of $1630-1650 \mathrm{~cm}^{-1}$ corresponds to the deformation vibrations of $\mathrm{OH}^{-}$water groups. The band of absorption $3150,3480 \mathrm{~cm}^{-1}$ corresponds to the valence vibration of water and characterizes the presence crystallization water. The values for the triplet of the valence vibration of the phosphate group $\delta_{\mathrm{v}}$ are close to those presented in [9-11]. A comparison between the IR-spectra of the calcium carbonate-phosphate samples and brushite $\mathrm{CaHPO}_{4} \cdot 2 \mathrm{H}_{2} \mathrm{O}$ formed from calcium oxide revealed a difference. It has been found that brushite is characterized by bands of absorption of valence vibration

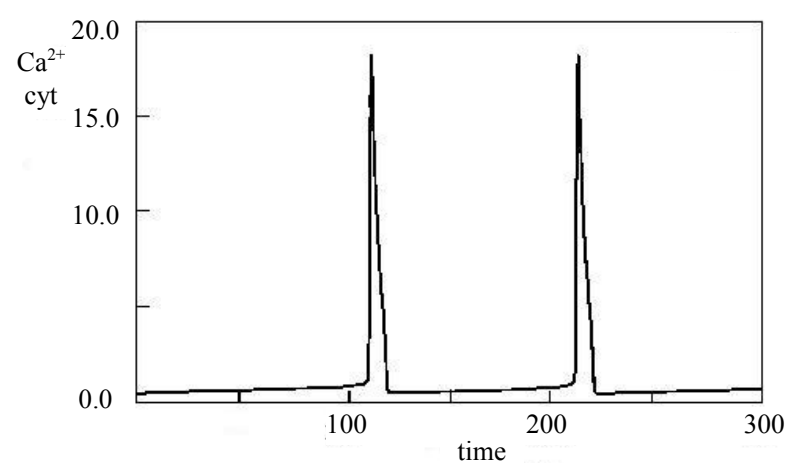

(a)

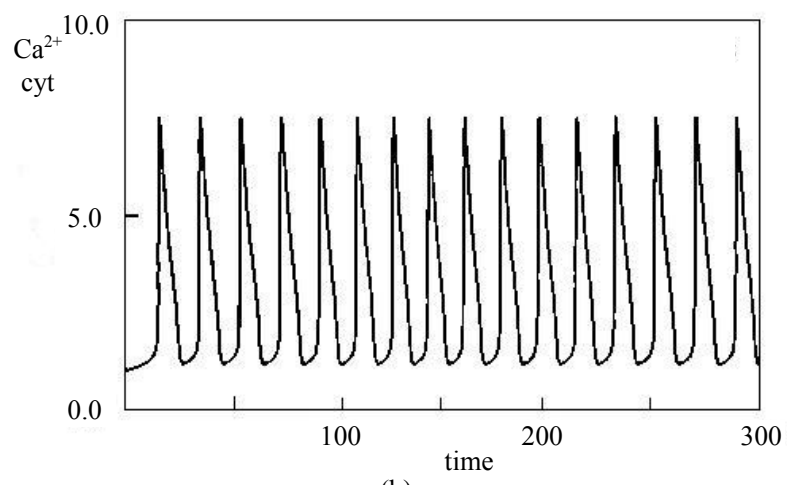

(b)

Figure 5. Model fluctuations in intracellular calcium. Kinetics of Ca concentration in different settings [33].

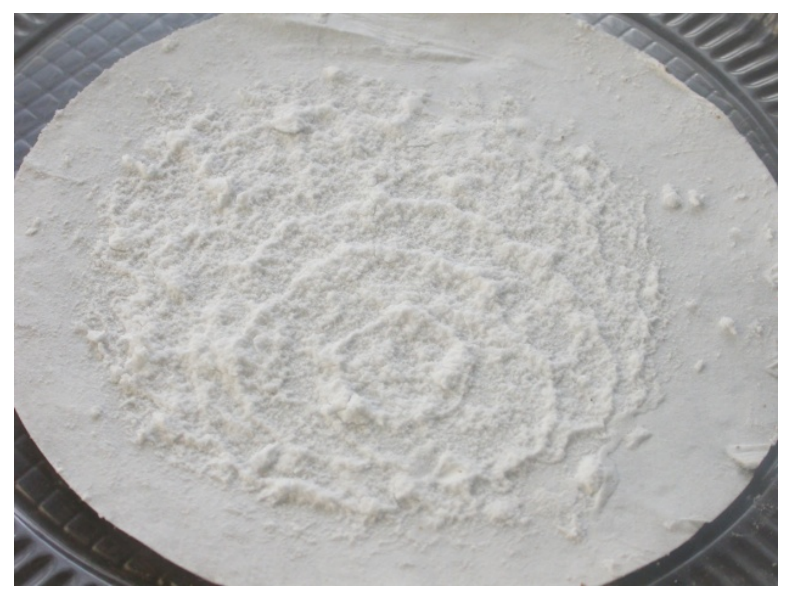

Figure 6. Oscillating character in the filtering and washing process of the doped calcium carbonate-phosphate precipitation.

$\delta_{\mathrm{v}}$ of group $\mathrm{PO}_{4}^{3+} 530,575,600 \mathrm{~cm}^{-1}$, bands of absorption of symmetric vibrations $v_{1} 790,870$ and $985 \mathrm{~cm}^{-1}$ and asymmetric vibrations $v_{3} 1060,1135$ and $1210 \mathrm{~cm}^{-1}$, as well as bands of absorption of deformation vibration of the $\mathrm{OH}^{-}$group $1645 \mathrm{~cm}^{-1}$.

DTG-analysis establishes that the calcium hydroxyapatite crystallization temperature is $840^{\circ} \mathrm{C}$, which proves to be true judging by the endothermic effect on the thermograph. At temperatures $130^{\circ} \mathrm{C}, 190^{\circ} \mathrm{C}$ and $240^{\circ} \mathrm{C}$, 


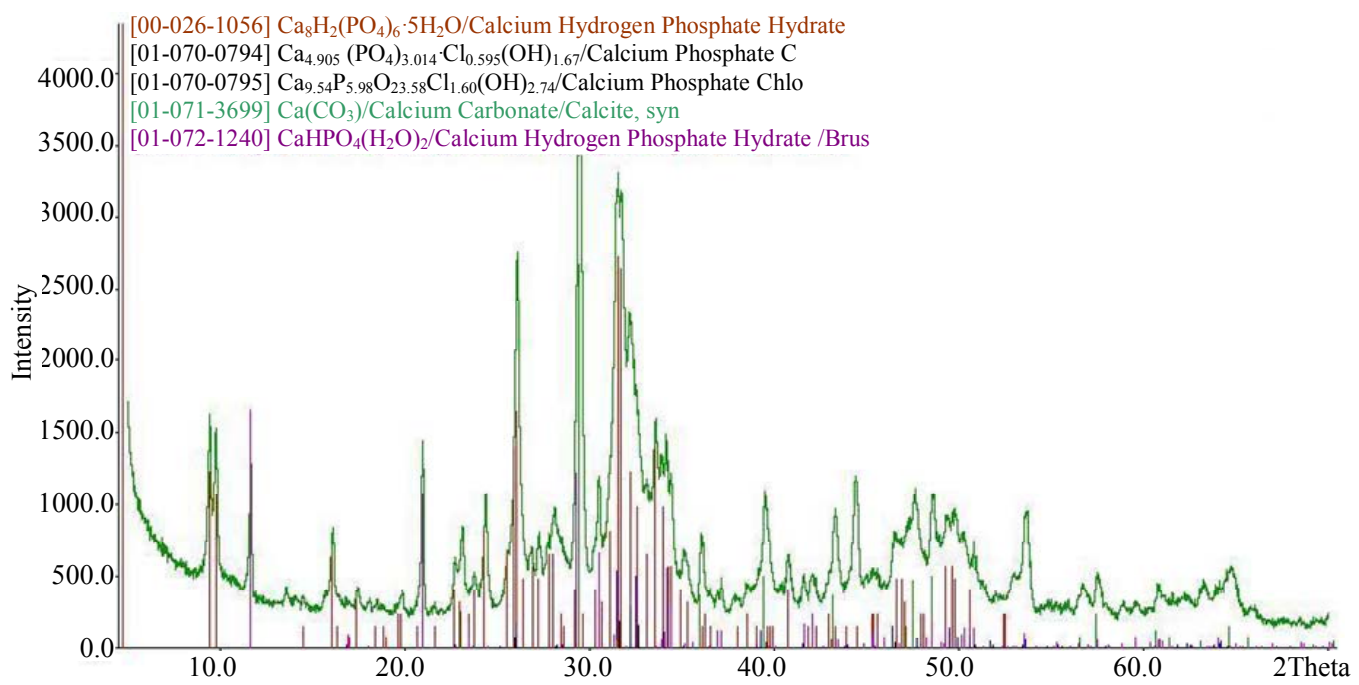

(a)

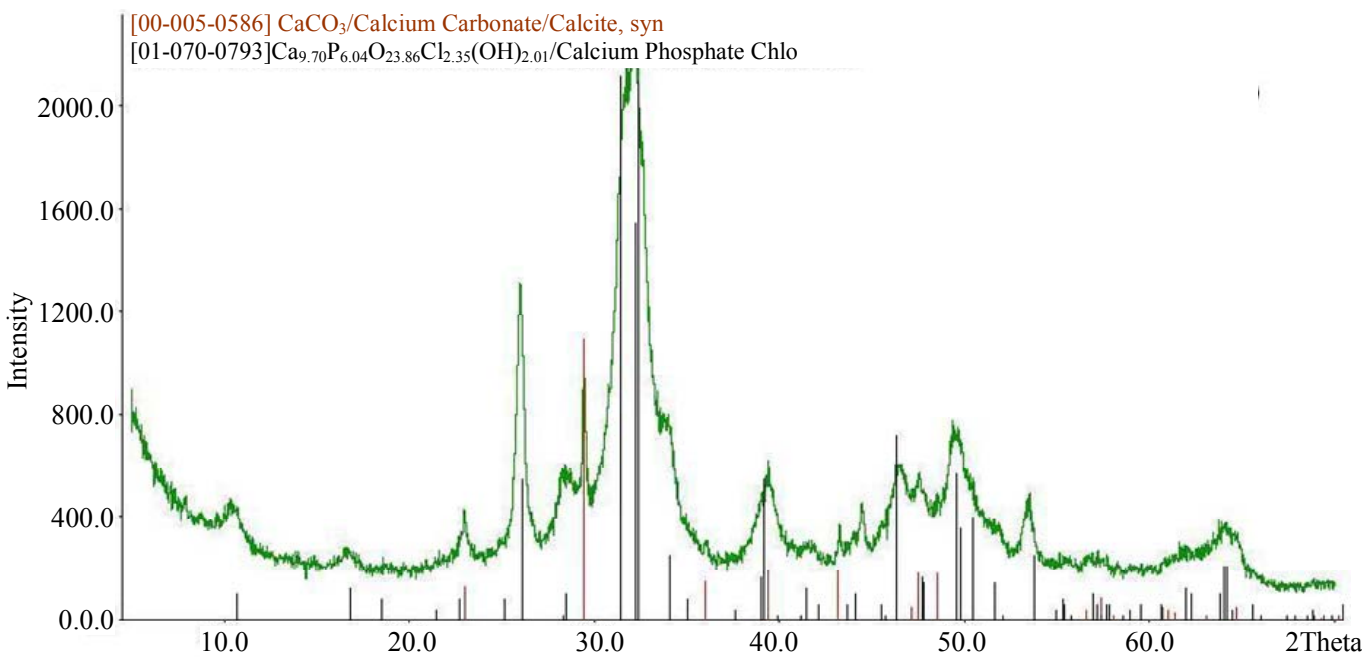

(b)

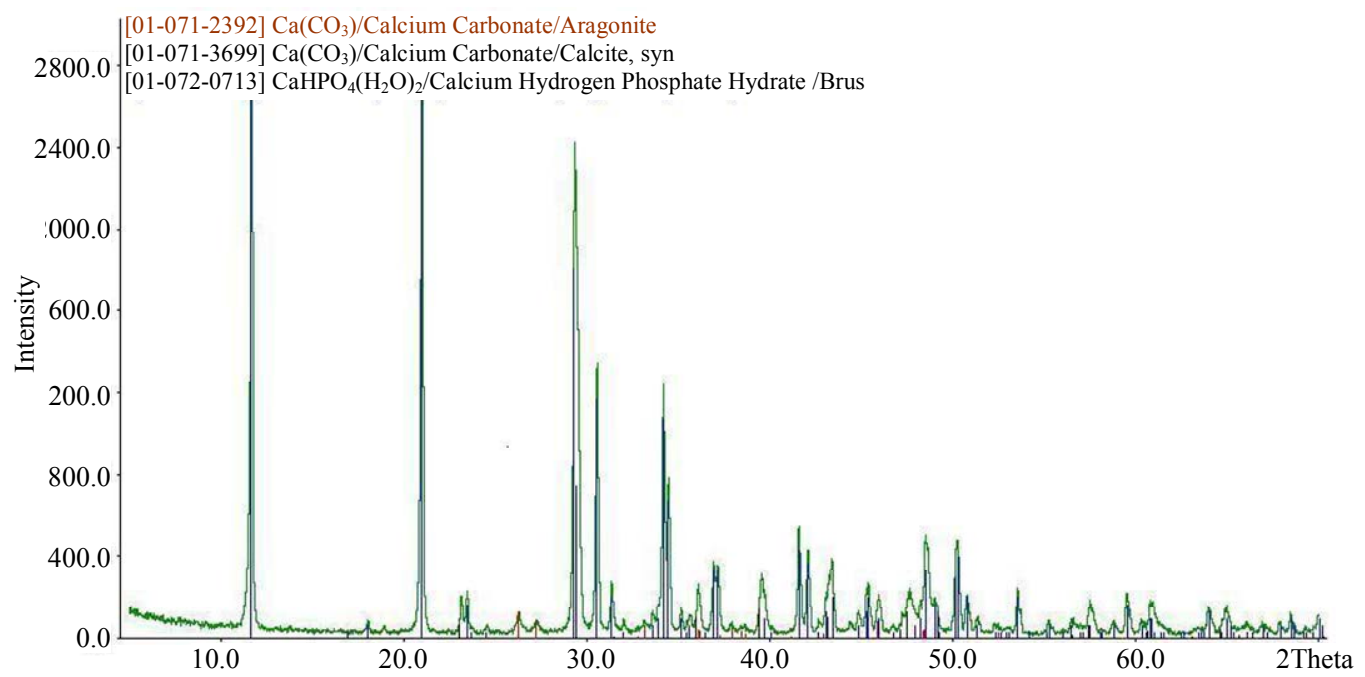

(c)

Figure 7. XRD patterns of (a) iron, magnesium, zinc doped; (b) iron, magnesium, zinc, manganese doped; (c) iron, magnesium, silica doped calcium carbonate phosphate. 


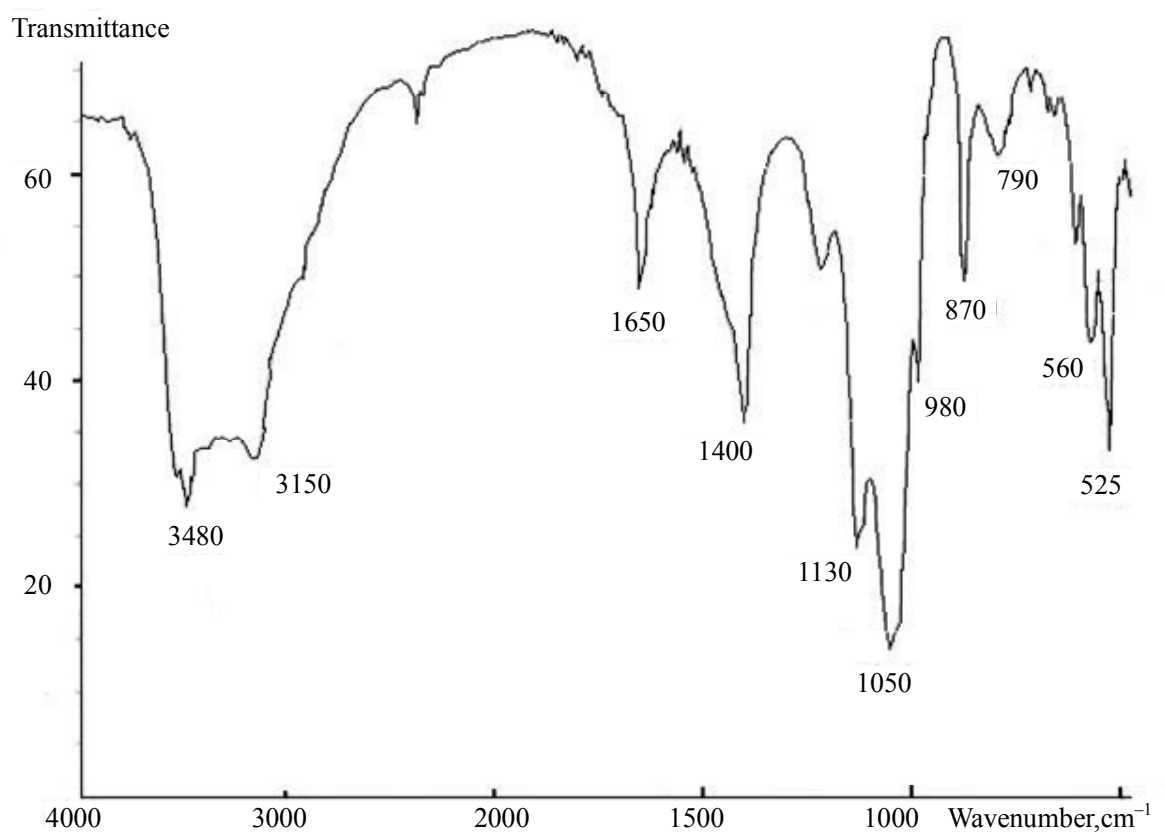

Figure 8. Typical IR-spectra of calcium carbonate-phosphate samples doped with iron, magnesium, zinc, manganese.

endothermic effects are caused by the dehydration of crystallization waters and the removal of hydrogen ions. The general loss of the weight of the samples dried up at a temperature of $75^{\circ} \mathrm{C}$ makes 17.5 to $18.5 \mathrm{wt} \%$, and this agrees well with the chemical and phase analysis (Figure 9).

Thermal treatment of iron-doped calcium carbonatephosphate samples in the range of temperatures from 900 to $1100^{\circ} \mathrm{C}$ leads to the formation of calcium hydroxyapatite having the composition

$$
\mathrm{Ca}_{9.868}\left(\mathrm{PO}_{4}\right)_{5.586}(\mathrm{OH})_{4.006}
$$

or, in the general form,

$$
\mathrm{Ca}_{10-x}\left(\mathrm{PO}_{4}\right)_{6-y}(\mathrm{OH})_{4+z}
$$

where $x=0.131 ; y=0.414 ; z=0.006$. X-ray diffraction lines of calcium hydroxyapatite crystals, with basic lines $2.819 ; 2.782 ; 2.726 \AA$. The data of the chemical analysis show that in calcium hydroxyapatite there is a cation vacancy equal to 1.028 . It is possible to explain this fact with the presence of free calcium channels appearing in course of the heat treatment of calcium carbonate-phosphate. As the sedimentation of calcium carbonate-phosphate was carried out in the ammonium chloride environment, it is likely that in the calcium channels there were cations of ammonium, and this may have an effect on the properties of calcium carbonate-phosphates as a biomaterial.

The total weight loss in samples dried at $75^{\circ} \mathrm{C}$ is $17.5 \%-18.5 \%$, in reasonable agreement with chemical and phase analysis data. Heat treatment of the iron/ magnesium doped samples at $950^{\circ} \mathrm{C}$ leads to the forma- tion of up to $79-80 \mathrm{wt}^{\%} \mathrm{Ca}_{9,54} \mathrm{P}_{5,98} \mathrm{O}_{23,58} \mathrm{Cl}_{1,60}(\mathrm{OH})_{2,74}$ with calcium triphosphate as a minor phase. Figure 10 shows a typical XRD pattern of iron/magnesium doped calcium carbonate phosphates calcined at $950^{\circ} \mathrm{C}$. Heat treatment of the magnesium/potassium doped samples leads to the formation of $\mathrm{Ca}_{4,905}\left(\mathrm{PO}_{4}\right)_{3,014} \mathrm{Cl}_{0,595}(\mathrm{OH})_{1,67}$ (up to $38 \%$ ) containing cation vacancies, and whitlockite, $\mathrm{Ca}_{2,993} \mathrm{H}_{0,014}\left(\mathrm{PO}_{4}\right)_{2}$ (upto $48 \%$ ), with

$\left.\mathrm{Ca}_{9,59}\left(\mathrm{PO}_{4}\right)_{5,75}(\mathrm{OH})_{2,29}\left(\mathrm{H}_{2} \mathrm{O}\right)_{0,92} \mathrm{H}_{0,97}\right)$ as a minor phase (15\%).

Thus, doping cations of $\mathrm{Fe}^{2+}, \mathrm{Mg}^{2}, \mathrm{Zn}^{2+} \mathrm{K}^{+}, \mathrm{Mn}^{2+}$ and $\mathrm{Si}^{4+}$ have an effect on the phase equilibrium in the system $\mathrm{CaCO}_{3}-\mathrm{H}_{3} \mathrm{PO}_{4}-\mathrm{NH}_{4} \mathrm{Cl}$, as well as on the end products of the process of sedimentation and their properties. It is calcium phosphate chloride and calcium hydrogen phosphate that are general crystal phases for iron- and magnesium-doped samples. The particle-size analysis has shown that the composition of calcium carbonate-phosphate samples is polydisperse. The basic fraction of particles ranges from 5 to 20 microns for samples doped with cations simultaneously. In addition the ultradispersed fraction with the size of particles up to $10 \mathrm{~nm}$ in amounts of $1.5 \%$ is observed, and this allows the material to be especially active in all the samples. It is noted that material dispersiveness enables the material to get through the skin of an organism. The characteristic curves of the particle-size analysis of the samples are adduced in Figure 10.

\subsection{Studying Biological Activity}

The influence of the doped calcium carbonate-phosphate 


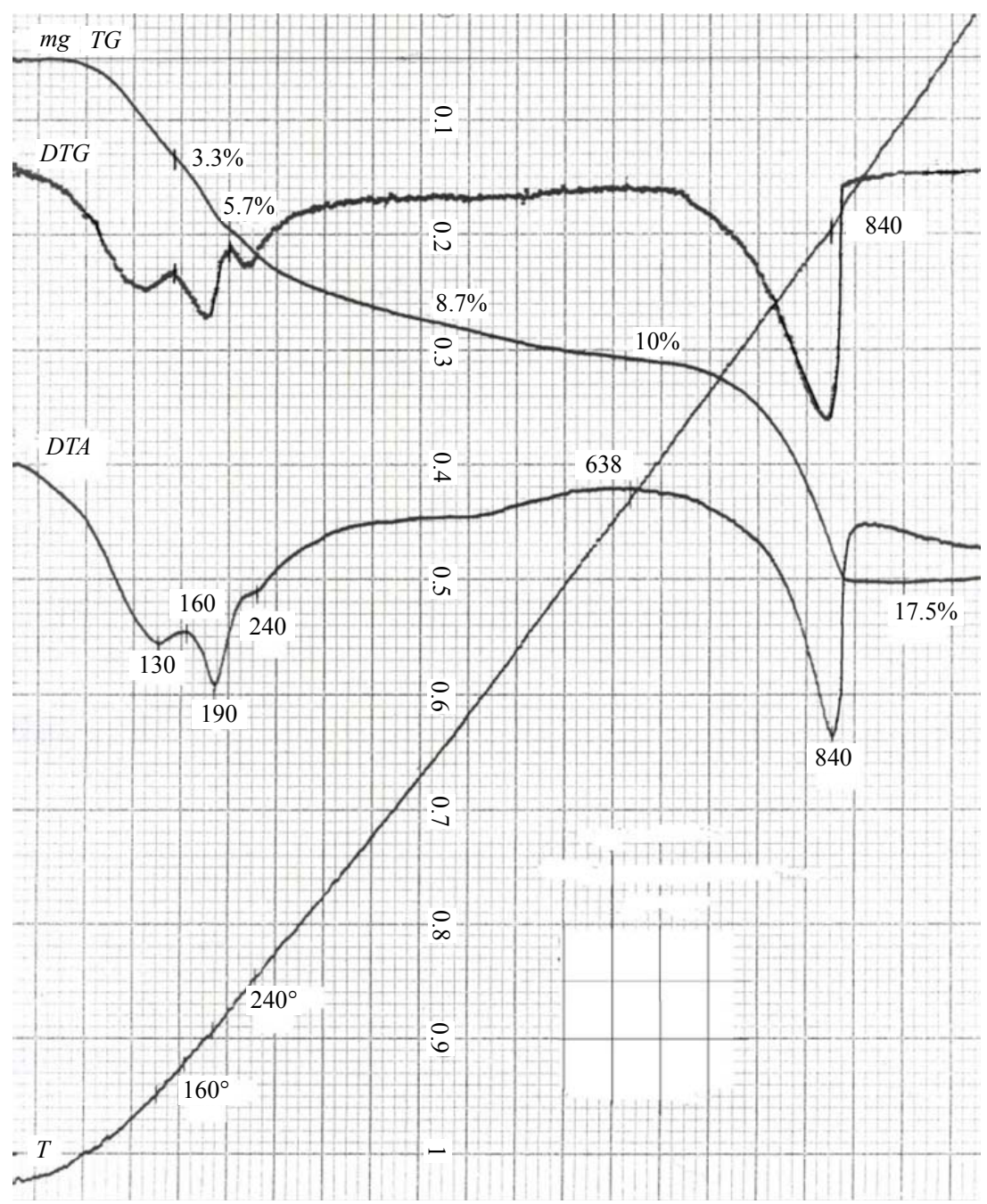

Figure 9. Characteristic DTA-curve of calcium carbonate-phosphate samples doped with cations of iron and magnesium.

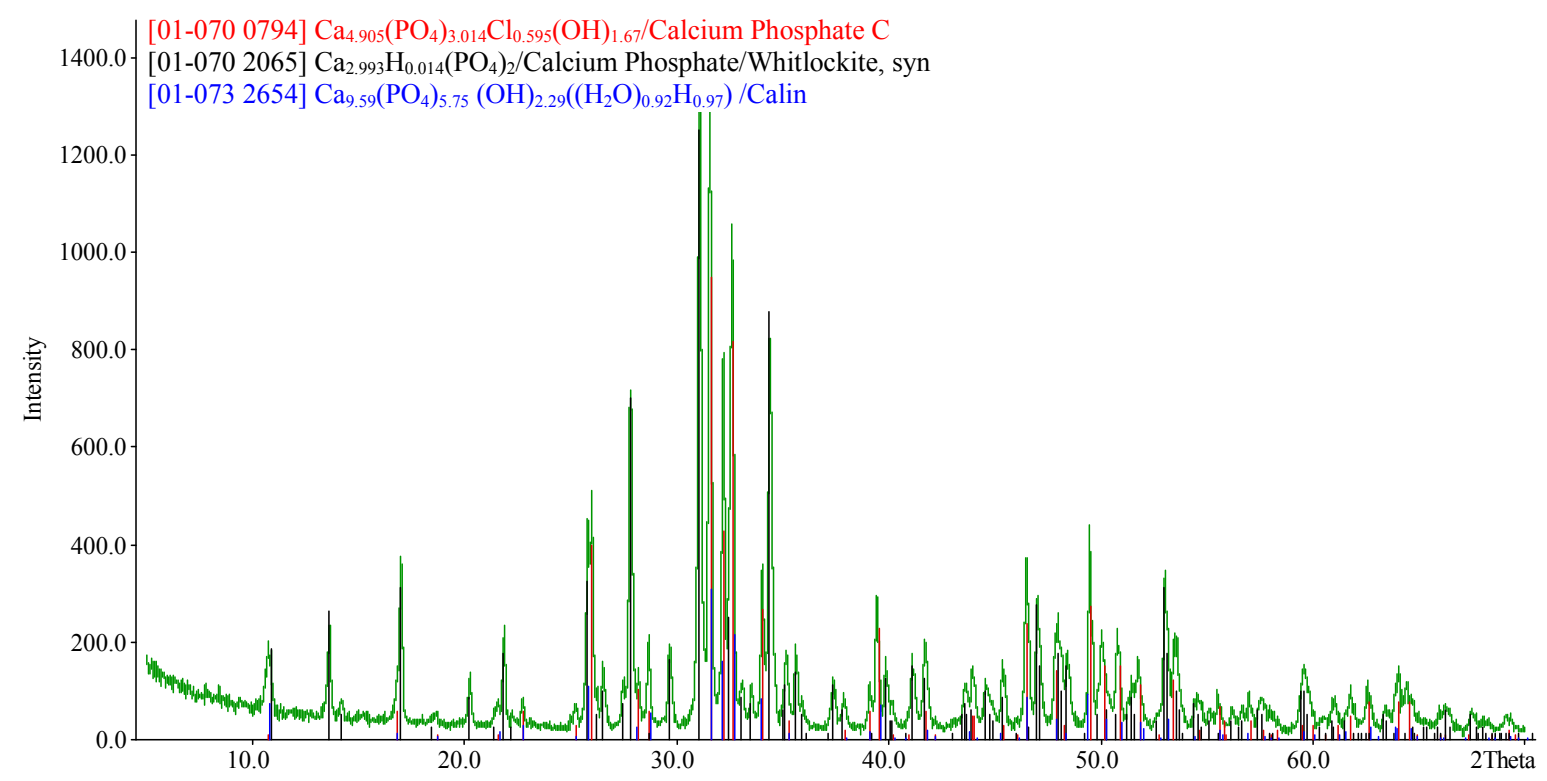

Figure 10. XRD patterns of iron, magnesium—doped calcium carbonate phosphate calcined at $950^{\circ} \mathrm{C}$. 
on the bone and dental tissues of a living organism was investigated experimentally in white rats. A $1 \%$ water suspension of calcium carbonate-phosphates was introduced inside animals through an enteric tube in amounts of $5 \mathrm{ml}$ within 40 days, $30 \mathrm{mg}$ per $1 \mathrm{~kg}$ of live weight (there were five groups of 10 animals, namely, I groupsplacebo, II groups-within 10 days, III groups-within 20 days, IV groups - within 30 days, V groups - within 40 days). The results are illustrated in Figure 11 showing the transverse mechanical strength (shear stress) of the bone tissue (femur) and the dental enamel as a function of the duration suspension introduction into animals. As a result, it has been found that there is a $13 \%$ increase in the mechanical strength (shear stress) of the bone tissue and a $7 \%$ increase in the strength of the dental tissue (enamel), and this enables us to make an assumption of strengthened osteogenesis in a living organism.

It is necessary to note that the first 10 days see a decrease in mechanical strength for the bone and dental tissues, and this is attributed to the insufficient number of receptors generated to assimilate calcium and phosphorus at the first stage. The results obtained have been processed by means of methods of mathematical statistics and the sampling has been verified for the normal distribution of the results. The comparison of the results with known ones [29] demonstrates a good agreement.

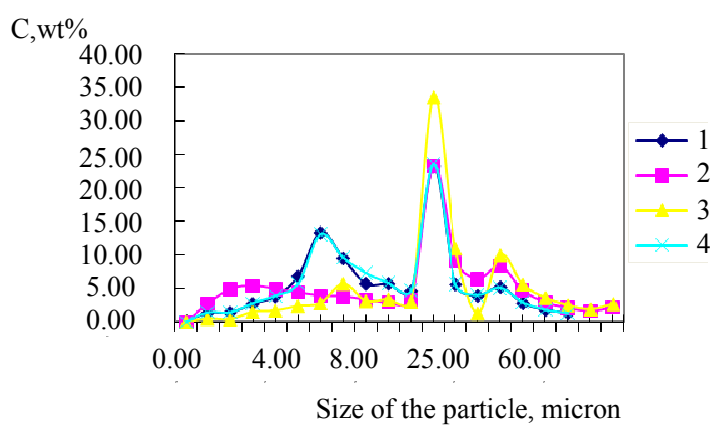

Figure 11. Differential particle size distributions of calcium carbonate phosphates prepared from them: (1) doped with $0.02 \mathrm{~mol} \%$ Fe; (2) doped with $0.02 \mathrm{~mol} \% \mathrm{Mg}$; (3) doped with $0.02 \mathrm{~mol} \% \mathrm{Fe}$ and $0.02 \mathrm{~mol} \% \mathrm{Mg}$; (4) undoped Cweight percent of size fraction.

The content of calcium, phosphorus in the bone tissue, as well as calcium, phosphorus, iron and magnesium in the dental enamel of animals as dependent on the introduction of calcium phosphates doped with magnesium and iron is presented in Table 2 and in Figure 12. The changes in the content of calcium, phosphorus in the bone tissue, as well as calcium, phosphorus, iron and magnesium in the dental enamel prove the activity of doped calcium carbonate-phosphate and their influence on osteogenesis.

Table 2. Effect of doped calcium carbonate-phosphate on the Ca, P, Mg and Fe concentration of the bone tissue and dental enamel.

\begin{tabular}{|c|c|c|c|c|c|c|c|c|}
\hline $\begin{array}{l}\text { Groups on } \\
10 \text { animals }\end{array}$ & $\begin{array}{l}\text { Ca-content of } \\
\text { the bone } \\
\text { tissue, wt. } \%\end{array}$ & $\begin{array}{l}\text { P-content of } \\
\text { the bone } \\
\text { tissue, wt. } \%\end{array}$ & $\begin{array}{l}\text { Ca-content of } \\
\text { dental } \\
\text { enamel, wt. } \%\end{array}$ & $\begin{array}{l}\text { P-content of } \\
\text { the dental } \\
\text { enamel, wt. } \%\end{array}$ & $\begin{array}{l}\text { Fe-content of } \\
\text { the dental } \\
\text { enamel wt. } \%\end{array}$ & $\begin{array}{l}\text { Standard } \\
\text { deviation } \\
\mathrm{S}^{2}\end{array}$ & $\begin{array}{l}\text { Mg-content of } \\
\text { the dental } \\
\text { enamel, wt. } \%\end{array}$ & $\begin{array}{c}\text { Standard } \\
\text { deviation } \mathrm{S}^{2}\end{array}$ \\
\hline I (placebo) & $40.25 \pm 0.05$ & $18.38 \pm 0.04$ & $37.28 \pm 0.04$ & $19.87 \pm 0.03$ & 0.78 & 0.07 & 0.06 & 0.01 \\
\hline II & $41.72 \pm 0.10$ & $16.74 \pm 0.12$ & $39.75 \pm 0.08$ & $17.26 \pm 0.08$ & 0.40 & 0.09 & 0.24 & 0.04 \\
\hline III & $40.06 \pm 0.07$ & $18.29 \pm 0.07$ & $37.49 \pm 0.04$ & $17.57 \pm 0.06$ & 0.63 & 0.03 & 0.26 & 0.01 \\
\hline IV & $41.53 \pm 0.12$ & $17.08 \pm 0.12$ & $37.51 \pm 0.03$ & $19.17 \pm 0.04$ & 0.92 & 0.05 & 0.16 & 0.01 \\
\hline V & $41.78 \pm 0.16$ & $16.99 \pm 0.14$ & $37.22 \pm 0.04$ & $19.60 \pm 0.03$ & 0.70 & 0.05 & 0.22 & 0.03 \\
\hline
\end{tabular}

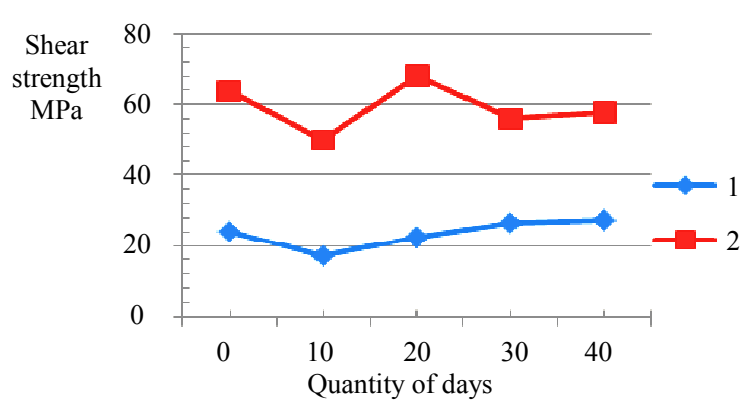

(a)

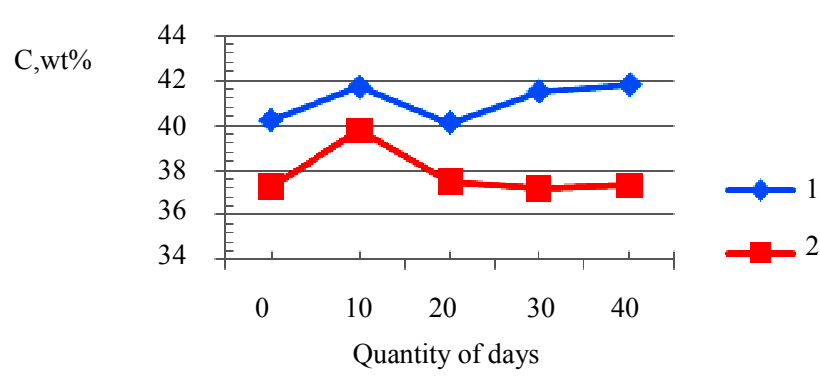

(b)

Figure 12. Influence of doped calcium carbonate-phosphate at shear strength bone tissue (curve 1, (a)) and of dental enamel from days quantity; change of calcium of the bone tissue (curve 1, (b)) and change of calcium of the dental enamel (curve 2, (b)) from days quantity of the suspension introduction. 


\section{Conclusion}

Thus, synthesized and investigated doped calcium carbonate-phosphate doped with cations represent a complex phase composition and constitute a biologically active material. The introduction of cations $\mathrm{Fe}^{2+}, \mathrm{Mg}^{2+}$, $\mathrm{Zn}^{2+}, \mathrm{K}^{+}, \mathrm{Mn}^{2+}$ and $\mathrm{Si}^{4+}$ changes the phase equilibrium in the $\mathrm{CaCO}_{3}-\mathrm{NH}_{4} \mathrm{Cl}-\mathrm{H}_{3} \mathrm{PO}_{4}$ system and leads to the formation of calcium phosphate chloride hydroxide, octacalcium hydrogen phosphate, brushite as the most active components participating in osteogenesis and the strengthening of the bone and dental tissues. By virtue of the kinetic data of the reaction of the interaction between orthophosphate acid and calcium hydroxycarbonate complexes in the synthesis process of nanocrystalline doped calcium carbonate phosphate, this system can be submitted as being chemically oscillating, i.e., oscillating in time. To describe this oscillating system, one can use a brusselator of the simplest cubic nonlinear realization. The kinetic curves of concentrated changes in the synthesis of nanocrystalline doped calcium carbonate phosphates are similar to the kinetics of concentration changes and phase pattern of the fructose-6-phosphate and fructose di-phosphate systems, respectively. The final reaction product output is determined as a result of oscillations. Doping cations have an impact on the formation of biologically active phosphate compounds. Doped calcium carbonate-phosphate are promising biocompatible materials designed to strengthen the bone and dental tissues and to replenish calcium in a living organism.

\section{Acknowledgements}

This research was funded by the Russian Basic Research Fund-Urals, project No 07-03-96076-[r].

\section{REFERENCES}

[1] M. N. Hughes, "The Inorganic Chemistry of Biological Processes," Mir Publishers, Moscow, 1983

[2] M. R. Sapin and G. L. Bilich, "Human Anatomy Vol. 1," Moscow, 2000.

[3] V. Y. Bibikov, V. V. Smirnov, I. V. Fadeeva, G. V. Ray, D. Ferro, S. M. Barinov and L. I. Shvorneva, "Intensification of Sintering Carbonate-Hydroxyapatite of Ceramics for Bone Implants," Perspectivniye Materialy, No. 6, 2005, pp. $43-48$.

[4] Y. D. Tretyakov, "Development of Inorganic Chemistry as a Fundamental Base for the Design of New Generations of Functional Materials," Russian Chemical Reviews, Vol. 73, No. 9, 2004, pp. 899-916.

[5] A. G. Veresov, V. I. Putlyaev and Y. D. Tretyakov, "Chemistry of Inorganic Biomaterials on the Basis of Calcium Phosphates," The Russian Chemical Journal of the Society, Vol. 48, No. 4, 2004, pp. 52-64.

[6] L. F. Koroleva, "Doped Calcium Phosphates-A Prom- ising Biomaterial, Perspectivniye Materialy, No. 4, 2007, pp. 30-36.

[7] L. F. Koroleva, "Doped Nanocrystalline Calcium Carbonate Phosphates," Inorganic Materials, Vol. 46, No. 4, 2010, pp. 405-411. doi:10.1134/S0020168510040151

[8] L. F. Koroleva, "An Oscillating Mechanism in the Synthesis of Doped Nanocrystalline Calcium Carbonate Phosphates," Nanotechnologies in Russia, Vol. 5, No. 9-10, 2010, pp. 635-640. doi:10.1134/S1995078010090077

[9] E. Bouyer, F. Gitzhofer and M. I. Boulos, "Morphological Study of Hydroxyapatite Nanocrystal Suspension," Journal of Materials Science: Materials in Medicine, Vol. 11, No. 8, 2000, pp. 523-531. doi:10.1023/A:1008918110156

[10] C. S. Liu, Y. Huang, W. Shen and J. H. Cui, "Kinetics of Hydroxyapatite Precipitation at $\mathrm{pH} 10$ to 11 ," Biomaterials, Vol. 22, No. 4, 2001, pp. 301-306. doi:10.1016/S0142-9612(00)00166-6

[11] G. V. Rodicheva, V. P. Orlovsky, V. P. Privalov, S. M. Barinov, F. S. Pustikelli and S. Oskarson, "Synthesis and Physical Chemical Research of Calcium Carbonate-Hydroxyapatite of Type," Journal Inorganic Chemistry, Vol. 46, No. 11, 2001, pp. 1798-1802.

[12] J. Cihlar and K. Castkova, "Direct Synthesis of Nanocrystalline Hydroxyapatite by Hydrothermal Hydrolysis of Alkylphosphates," Monatshefte für Chemie/Chemical Monthly, Vol. 133, No. 6, 2002, pp. 761-771.

[13] C. Tasi and F. Aldinger, "Formation of Apatitic Calcium Phosphates in a Na-K-Phosphate Solution of $\mathrm{pH}$ 7.4," Journal of Materials Science: Materials in Medicine, Vol. 16, No. 2, 2005, pp. 167-174. doi:10.1007/s10856-005-5919-5

[14] S. M. Barinov and V. S. Komlev, "Calcium Phosphate Based Bioceramics," Nauka, Moscow, 2005.

[15] R.-X. Sunl and Y.-P. Lu, "Fabrication and Characterization of Porous Hydroxyapatite Microspheres by Spraydrying Method," Frontiers of Materials Science in China, Vol. 2, No. 1, 2008, pp. 95-98. doi:10.1007/s11706-008-0017-5

[16] L. Hong, M. Y. Zhu, L. H. Li and C. R. Zhou, "Processing of Nanocrystalline Hydroxyapatite Particles via Reverse Microemulsions," Journal of Materials Science, Vol. 43, No. 1, 2008, pp. 384-389. doi:10.1007/s10853-007-2182-9

[17] S. Peroos, Z. M. Du and N. H. de Leeuw, "A Computer Modeling Study of Uptake, Structure and Distribution of Carbonate Defects in Hydroxyl-Apatite," Biomaterials, Vol. 27, No. 9, 2006, pp. 2156-2161. doi:10.1016/j.biomaterials.2005.09.025

[18] N. V. Kitikova, I. L. Shashkova, Y. G. Zonov, O. A. Sycheva and A. I. Rat'ko, "Effect of Phase Transformations during Synthesis on the Chemical Composition and Structure of Calcium-Deficient Hydroxyapatite," Inorganic Materials, Vol. 43, No. 10, 2007, pp. 319-324. doi: $10.1134 / \mathrm{S} 0020168507100160$

[19] A. S. Fomin, S. M. Barinov, V. M. Ievlev, V. V. Smirnov, B. P. Mikhailov, E. K. Belonogov and N. A. Drozdova, "Nanocrystalline Hydroxyapatite Ceramics Produced by Low-Temperature Sintering after High-Pressure Treat- 
ment," Doklady Chemistry, Vol. 418, No. 1, 2008, pp. 22-25. doi:10.1134/S0012500808010084

[20] R.-X. Suni and Y.-P. Lu, "Fabrication and Characterization of Porous Hydroxyapatite Microspheres by Spraydrying Method," Frontiers of Materials Science in China, Vol. 2, No. 1, 2008, pp. 95-98. doi:10.1007/s11706-008-0017-5

[21] Y. Ling, J, Han, S. Chye, J. Loo, N. T. Phung, F. Boey and J. Ma, "Controlled Size and Morphology of EDTMPDoped Hydroxyapatite Nanoparticles as Model for ${ }^{153} \mathrm{Sa}-$ marium-EDTMP doping," Journal of Materials Science: Materials in Medicine, Vol. 19, No. 9, 2008, pp. 29933003. doi:10.1007/s10856-008-3426-1

[22] I. S. Neira, Y. V. Kolen'ko, O. I. Lebedev, G. Van Tendeloo, H. S. Gupta, N. Matsushita, M. Yoshimura and F. Guitian, "Rational Synthesis of a Nanocrystalline Calcium Phosphate Cement Exhibiting Rapid Conversion to Hydroxyapatite," Materials Science and Engineering: C, Vol. 29, No. 7, 2009, pp. 2124-2132. doi:10.1016/j.msec.2009.04.011

[23] J. V. R. Generosi, V. R. Albertini, B. Paci, "Crystallization Process of Carbonate Substituted Hydroxyapatite Nanoparticles in Toothpastes upon Hysiological Conditions: An in Situ Time-Resolved X-Ray Diffraction Study," Journal of Materials Science: Materials in Medicine, Vol. 21, No. 2, 2010, pp. 445-450. doi:10.1007/s10856-009-3905-Z

[24] M. Hazegawa, Y. Doi and A. Uchida, "Cell-Mediated Bioresorption of Sintered Carbonate Apatite in Rabbits," Journal of Bone and Joint Surgery, Vol. 85, No. 1, 2003, pp.142-147.

[25] M. Mullender, A. J. El Haj, Y. Yang, M. A. van Duin, E. H. Burger and I. J. Klein-Nulend, "Mechanotransduction of Bone Cells in Vitro: Mechanobiology of Bone Tissue," Medical \& Biological Engineering \& Computing, Vol. 42, No. 1, 2004, pp. 14-21.

[26] C. Lai, Y. J. Wang and K. Wei, "Nucleation Kinetics of Calcium Phosphate Nanoparticles in Reverse Micelle Solution," Colloids and Surfaces A: Physicochemical and Engineering Aspects, Vol. 299, No. 1-3, 2007, pp. 203208. doi:10.1016/j.colsurfa.2007.08.009

[27] J. Brandt, S. Henning, G. Michler, W. Hein, A. Bernstein and M. Schulz, "Nanocrystalline Hydroxyapatite for Bone Repair: An Animal Study," Journal of Materials Science: Materials in Medicine, Vol. 21, No. 1, 2010, pp. 283-294. doi:10.1007/s10856-009-3859-1

[28] D. G. Peters, J. M. Hayes and G. M. Hieftje, "Chemical Separations and Measurements: Theory and Practice of Analytical Chemistry," Saunders, New York, 1974.

[29] J. German and H. Liebowitz, "Mechanics of Destruction of the Bone Tissue," In: H. Liebowitz, Ed., Fracture of Nonmetals and Composites, Mir Publishers, Moscow, 1976, pp. 391-463.

[30] L. F. Koroleva, L. P. Larionov and N. P. Gorbunova, "Doped Calcium Carbonate Phosphates-An Effective Ultradispersed Biomaterial for Substitution and Strengthening of Bony Tooth Tissues," Proceedings of the International Forum on Nanotechnologies "Rusnanotech 08," Moscow, 3-5 December 2008, pp. 505-507.

[31] I. R. Prigozhine and R. Lefebre, "Symmetry Breaking Instabilities Indissipative Systems," Journal of Chemical Physics, Vol. 48, 1968, pp. 1665-1700. doi: $10.1063 / 1.1668896$

[32] R. J. Field and M. Burger, "Oscillations and Traveling Waves in Chemical Systems," Wiley, New York, 1985.

[33] J. A. Higgins, "A Chemical Mechanism for Oscillations in Glicolitic Intermediates in Yeast Cells," Proceedings of the National Academy of Sciences, Vol. 51, No. 6, 1954, pp. 989-994.

[34] J. A. Higgins, "The Theory of Oscillating Reactions," Industrial \& Engineering Chemistry, Vol. 59, No. 5, 1967, pp. 18-62. doi:10.1021/ie50689a006

[35] G. Dupont and A. Goldbetter, "Theoretical Insights into the Origin of Signal-Induced Calcium Oscillations: From Experiments to Theoretical Models," Academic Press, London, 1989.

[36] G. Dupont and A. Goldbetter, "Protein Phosphorylation Driven by Intracellular Calcium Oscillations: A Kinetic Analysis, Biophysical Chemistry, Vol. 42, No. 2, 1992, pp. 257-270. doi:10.1016/0301-4622(92)80018-Z

[37] G. Dupont and A. Goldbetter, "Oscillations and Waves of Citosolic Calsium: Insights from Theoretical Models," BioEssays, Vol. 14, No. 7, 1992, pp. 485-493. doi:10.1002/bies.950140711 